\title{
The Role of Self-Regulation in Finishing Final Task of Vocational Higher Education Student
}

\author{
Muhammad Yahya \\ Engineering Faculty \\ Universitas Negeri Makassar \\ Makassar, Indonesia
}

\author{
Anas Arfandi \\ Engineering Faculty \\ Universitas Negeri Makassar \\ Makassar, Indonesia
}

\begin{abstract}
This study aims to elaborate the self-regulation of the student in applying final task. This study also describes the relationship between the dimensions of motivation (M) among final task (FT) of VHE students in Makassar as well as the relationship between the dimensions of epistemological beliefs (EB) among final task (FT) of VHE students in Makassar. Also, this study explains self-regulation in predict applied final task of VHE student in Makassar. This study is a survey research. The research was taken on September to December 2016 in Makassar city. The subjects were the students of vocational higher education of Faculty of Engineering, Universitas Negeri Makassar. The samples were taken using random cluster sampling as many as 70 students, from 6 study program. The data collected using questionnaires and structured interviews. This study found that the dimensions of self-regulation in the aspect of motivation do not significantly affect the final task completion. The aspects of epistemological beliefs have a significant positive relationship to the conclusion of the final task. So that, the study has implicated for the improvement of academic supervisor's role in encouraging students to motivate them in completing the final task as well as the possible and expected duration of the study that can achieve the target of 3 years.
\end{abstract}

Keywords- motivation; epistemological beliefs; final task; vocational higher education.

\section{INTRODUCTION}

Vocational training expected students to optimise the Selfregulation (SR) held to improve the competence to be achieved. The final task (FT) is a final review of the study and a student achievement before passed in a course. In last five years, the students of Vocational Higher Education (VHE) average used three years and nine months to finish their study. However, the average of students is good enough that at 3.29 Grade-Point Average (GPA).

Self-regulation (SR) refers to the thoughts, feelings, and actions planned and tailored to personal goals [1]. [2] stated that SR equally to self-control. In the context of learning, [3] explains that the learning outcomes is a relatively permanent change of the result of knowledge and skills through experience possessed.
SR associated with learning refers to the process of directing and self-belief that can transform the mental abilities of students into academic performance skills, such as verbal talent becomes capacity to write, named self-regulated learning (SRL) [4]. Therefore, ] the research of the link processes with the academic outcome, especially related to the relationship of the SR and SRL [5. The purpose of the study is to elaborate the self-regulation of the student in applying final task. This study also describes the relationship between the dimensions of motivation (M) among final task (FT) of VHE students in Makassar. Also, this study describes the relationship between the dimensions of epistemological beliefs (EB) among final task (FT) of VHE students in Makassar.

\section{RESEARCH METHOD}

This study is a survey research. The research was taken on September to December 2016 in Makassar city. The subjects were the students of vocational higher education of Faculty of Engineering, Universitas Negeri Makassar. The population of the research was all student who taken the Final Task Subject in academic year 2015/2016. The samples were taken using random cluster sampling as many as 70 students, from 6 study program.

The variable of the research is the self-regulation which consists of variable motivation $\left(\mathrm{X}_{1}\right)$ and epistemological belief $\left(\mathrm{X}_{2}\right)$ as the independent variable. Motivation variable indicates from self-efficacy, goal orientation, and task interest. While Epistemological Beliefs variable shows the speed of knowledge acquisition, knowledge construction and modification, the certainty of knowledge, and control of knowledge acquisition. The Final Task (Y) as dependent variable indicated with the relevant, the type, and the impact of the final task. The data collected using questionnaires and structured interviews. The data were analysed used descriptive and inferential statistic.

\section{RESULT}

The descriptive of the respondent shows that $57.14 \%$ of respondents were male and $42.86 \%$ are women whose average age was 21 years. $28.57 \%$ of respondents are students who acted in the organisation and male students dominate them. The descriptive of the data shows in Figure 1. 


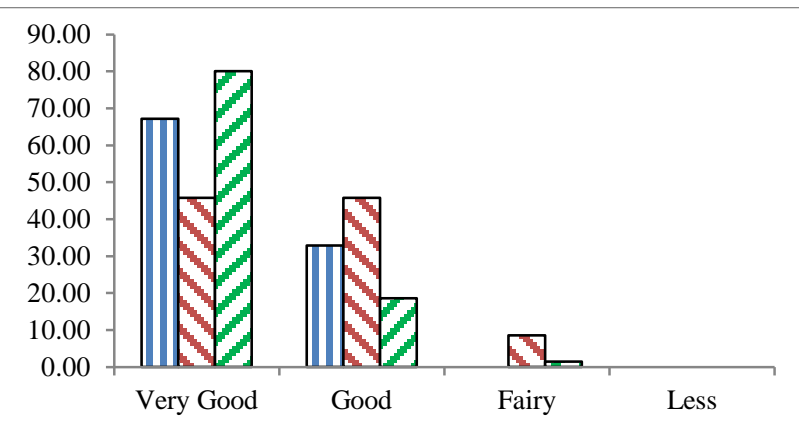

I Motivation घEpistemological Beliefs $\quad$ 口Final Task

Fig. 1. The category of the variable

Figure 1 describes the preparation of the final task performed by the students has been excellent. However, there are still about $1 \%$ of which is sufficient. Student motivation in preparing FT already very good, which amounted to $80 \%$, while the motivation amount $67 \%$, and the epistemological beliefs only around $45 \%$. In another side, the Fairy category contained almost $10 \%$ in Epistemological beliefs and amounted $2 \%$ in Final Task variable.

To analyse the data using inferential analysis, the data should meet the pre-analysis test such as Normality, Homogeneity, and Linearity. Normality test using the Kolmogorov-Smirnov test results $\mathrm{p}$ values obtained for the variable $\mathrm{X}_{1}$ for 1.179 , amounting 1.051 for $\mathrm{X}_{2}$ variable, and 1.388 for variable $\mathrm{Y}$. It indicates that the data was normally distributed considering the value of $\mathrm{p}>.05$.

In the homogeneity test values obtained sig. variable $X_{1}$ of .143 , and variable $\mathrm{X}_{2} .086$. So this indicates that the data obtained is homogeneous. The linearity test between $X_{1}$ and $Y$ obtained a value of .644 while linearity test between $\mathrm{X}_{2}$ and $\mathrm{Y}$ obtained a value of .986 . The second value is greater than the significance level of .05 , so it can be said that both the variable $\mathrm{X}$ has a linear relationship to the $\mathrm{Y}$. With the fulfilment of all three of these requirements, then the regression testing can proceed.

TABLE 1. THE SUMMARY OF CORRELATION MATRIX

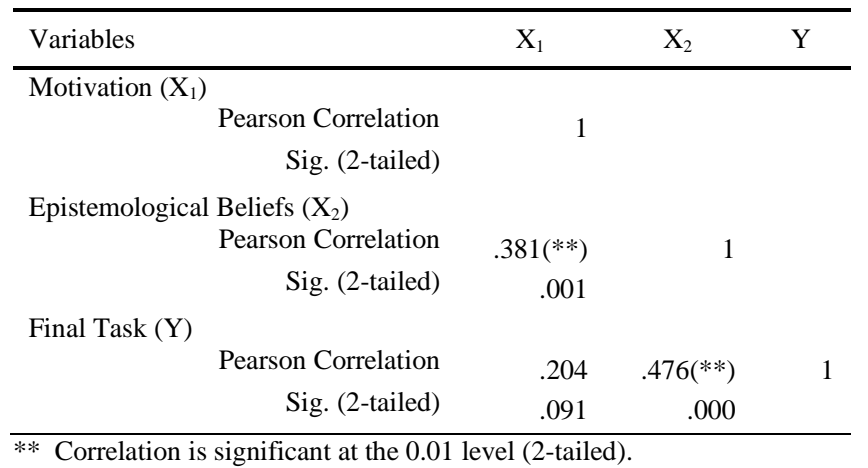

H-01 There is a significant relationship between the dimensions of motivation $\left(\mathrm{X}_{1}\right)$ among final task (Y)of VHE students in Makassar. The findings of this study from the structural analysis indicate that there is a positive relationship between motivation and final task $(r=.204, \mathrm{P}>.05)$. Therefore the null hypothesis is rejected.

H-02 There is a significant relationship between the dimensions of motivation $\left(\mathrm{X}_{1}\right)$ among epistemological beliefs $\left(\mathrm{X}_{2}\right)$ of VHE students in Makassar. The findings of this study from the structural analysis indicate that there is a positive relationship between motivation and epistemological beliefs $(\mathrm{r}=.381, \mathrm{P}<.05)$. Therefore the null hypothesis is rejected.

H-03 There is a significant relationship between the dimensions of epistemological beliefs among final task of VHE students in Makassar. The findings of this study from the structural analysis indicate that there is a positive relationship between epistemological beliefs (EB) and final task acquisition approach $(\mathrm{r}=.476, \mathrm{P}<.05)$. Therefore the null hypothesis is accepted.

\section{DISCUSSION}

The study investigates the relationship between two dimensions of self-regulation motivation and epistemological beliefs, in predicting final task implementation among VHE students of Universitas Negeri Makassar in Makassar. The following relationships were revealed: the motivation was found to be no significant related to final task implementation. More so the findings of this study were consistent with the conclusions from the previous literature and theoretical expectations.

This survey found that there was no correlation between motivation and the completion of the final project. However, the unusual relationship was revealed in the correlation analysis in this study, where the result revealed the insignificant relationship between motivation and final task, this finding contradicts the finding from the previous literature and the theoretical expectations. These results contradict the theoretical expectations of motivation for academic attainment [6] and a conceptual framework for assessing motivation [7]. It also unsupported the descriptive result which describes the motivation of the students is dominantly very good.

Student motivation that shows no correlation to the completion of the final task becomes an important aspect that must be considered by the supervisor of the final task. It could affect students preparation in completing their study which will further influence the readiness of students in the real world [8]. Several studies [9], [10] indicate that career counselling can directly influence student readiness, and may also indirectly influence work motivation.

Considering to these conditions, [9] suggested that to improve the competence and competitiveness of graduates, it is necessary: (1) to diversify the competence of graduates through increasing the relevance of the curriculum oriented towards the improvement of basic jurisdiction of personality; (2) application of learning model based on Total Quality Management (TQM); (3) strengthening partnerships in learning with various stakeholders; and (4) optimizing strategic leadership in curriculum restructuring based on the superiority of personality and secularization of traditional learning into quality-based learning. 
This study finding epistemological beliefs and final task there is a significant positive relationship. This finding was conformity the findings from the previous literature [10]. This study also support the theoretical expectations [11] and confirms the study of [12] about the dimensions of epistemological beliefs, learning goal orientation, as predictors of deep knowledge acquisition approach. In this case, also the null hypothesis is not supported.

\section{CONCLUSION AND IMPLICATION}

Based on the findings and discussion, this study concluded that the dimensions of self-regulation in the aspect of motivation does not significantly affect the final task completion; 2) aspects of epistemological beliefs has a significant positive relationship to the conclusion of the final task. This study has implicated for the improvement of academic supervisor's role in encouraging students to motivate them in completing the final task as well as the possible and expected duration of the study that can achieve the target of 3 years. Also, the strengthening of epistemological beliefs still needs to be optimised considering a significant contribution in the completion of students' final task. Also, the enhancement of epistemological beliefs still needs to be optimised considering an important contribution in the completion of students' final task.

\section{ACKNOWLEDGEMENTS}

The author would like special thank you for Direktorat Penguatan Riset and Pengembangan (DPRM) Ministry of Research Technology and Higher Education of Indonesia which funding this research.

\section{REFERENCE}

[1] B. J. Zimmerman, "Becoming a self-regulated learner: An overview," Theory Pract., vol. 41, no. 2, pp. 6470, 2002.

[2] K. D. Vohs and R. F. Baumeister, Handbook of selfregulation: Research, theory, and applications. Guilford Publications, 2016.

[3] J. B. Vancouver, "Self-regulation in organizational settings: A tale of two paradigms.," 2000.

[4] B. J. Zimmerman, "Investigating self-regulation and motivation: Historical background, methodological developments, and future prospects," Am. Educ. Res. J., vol. 45, no. 1, pp. 166-183, 2008.

[5] D. H. Schunk, "Metacognition, self-regulation, and self-regulated learning: Research recommendations," Educ. Psychol. Rev., vol. 20, no. 4, pp. 463-467, 2008.

[6] B. J. Zimmerman, A. Bandura, and M. Martinez-Pons, "Self-motivation for academic attainment: The role of self-efficacy beliefs and personal goal setting," Am. Educ. Res. J., vol. 29, no. 3, pp. 663-676, 1992.

[7] P. R. Pintrich, "A conceptual framework for assessing motivation and self-regulated learning in college students," Educ. Psychol. Rev., vol. 16, no. 4, pp. 385-
407, 2004.

[8] A. Arfandi, "Relevansi Kompetensi Lulusan Diploma Tiga Teknik Sipil di Dunia Kerja," J. Pendidik. Vokasi, vol. 3, no. 3, 2013.

[9] A. Dardiri, "Diversifikasi Kompetensi Lulusan Pendidikan dan Latihan Vokasi untuk Lebih Kompetitif," Teknol. dan Kejuru., vol. 34, no. 1, 2011.

[10] L. Rodriguez and F. Cano, "The learning approaches and epistemological beliefs of university students: a cross- sectional and longitudinal study," Stud. High. Educ., vol. 32, no. 5, pp. 647-667, 2007.

[11] M. Schommer, "Effects of beliefs about the nature of knowledge on comprehension.," J. Educ. Psychol., vol. 82, no. 3, p. 498, 1990 .

[12] M. H. Jikamshi, M. C. Abdullah, S. Roslan, and H. Ismail, "Dimensions of Epistemological Beliefs, Learning Goal Orientation, as Predictors of Deep Knowledge Acquisition Approach among Pre-Service Teachers in Nigeria," Mediterr. J. Soc. Sci., vol. 7, no. 4, p. 165, 2016. 